\title{
机上にかかる圧力を用いたユーザの割り込み可能 性推定
}

\section{Estimating a User's Interruptibility by Using Tabletop Pressure}

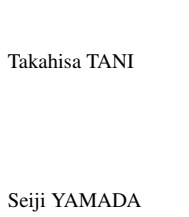

\author{
総合研究大学院大学 複合科学研究科 情報学専攻 \\ Department of Informatics, School of Multidisciplinary Sciences, The Graduate University for Advanced Studies \\ tani@nit.ac.jp \\ 国立情報学研究所 / 総合研究大学院大学/東京工業大学 \\ National Institute of Informatics, The Graduate University for Advanced Studies, Tokyo Institute of Technology \\ seiji@nii.ac.jp, http://www.ymd.nii.ac.jp/lab/seiji/
}

keywords: user state estimate, interruptibility, tabletop pressure

\begin{abstract}
Summary
In the current office environment connected to the Internet, a user tends to get a lot of notifications in the form of e-mails, micro-blogs, instant messages, application update alerts, and so on. A significant problem with such notifications is that they arrive as they are sent, i.e., without the system being aware of whether the user has time to receive them or not. If messages arrive at inopportune times, they can cause serious stress and reduce the user's productivity. One way of alleviating this problem would be to control the notification period in accordance with the user's state of activity. In other words, this means a system needs to estimate whether a user is interruptible or not and to send information only when he/she is interruptible There are a number of studies to estimate use state (e.g. monitor user behaviors like typing, operating a mouse, facial expression and so on). However, these methods has some problems. In this paper, we develop a novel method for estimating user states. Our method use a pressure on a desk. We use a lattice-like pressure sensor sheet and distinguish between two simple user states: interruptible or not. The pressure can be measured without the user being aware of it, and changes in the pressure reflect useful information such as typing, an arm resting on the desk, mouse operation, and so on. We carefully developed features that can be extracted from the sensed raw data, and we used a machine learning technique to identify the user's interruptibility. We conducted experiments for two different tasks to evaluate the accuracy of our proposed method and obtained promising results.
\end{abstract}

\section{1. は じめ に}

近年の情報化社会において, ユーザは多くの情報通 知 (notification) を受け取りながら仕事や生活をしてい る [Iqbal 10] . その例として , メールやインスタントメッ セージなどの着信, 樣々なアプリケーションのUpdate な どのアラートが挙げられる .これらの情報通知は, ユーザ が能動的に情報を入手するのではなく, システムがユー ザに対して情報を提示する形式を取る．ここで生じる問 題として，情報通知タイミングの妥当性が挙げられる． 情報通知のタイミングが適切でなければ, ユーザに不要 なストレスを与えることになるのみならず , 知的生産性 が低下する可能性か指摘されている [Bailey 01]. 谷こで， ユーザの状態を考慮した情報通知の制御が必要となる。 つまり，ユーザが情報通知を受理できる割り込み可能状 態 (interraptable state) であるかどうかを推定し, 谷の状 態のときに情報を通知することが望ましい．

また一方, ユーザの割り込み可能状態を推定しないア
プローチもある .メインタスクのウインドウやディスプレ イの横にサブウインドウやサブディスプレイをメインタ スクの遂行に干渉しないように配置して，光こに情報通 知内容を表示するペリフェラルディスプレイ [McCrickard 01, Kim 10]が兴のようなアプローチの典型であるが , 本 研究では, 情報通知以外の目的にも適用するこを想定し て , ユーザ状態を推定する方法を採用する .

ユーザ状態推定のためにはユーザを観測することが必 要である . キーやマウスの入力の頻度やタイミングを用 いてユーザの繁閑や感情の状態を推定する手法が提案さ れている [Epp 11, 水口 04, 本田 98] . しかしこの手法で は, 入力の頻度が必ずしもユーザの繁閑を反映していな い場合に情報提示タイミングの推定ができないことや， ユーザが入力装置を利用していない場合には推定できな いなどの問題がある .

また，PC 作業の切れ目度合いを推定する手法 [Iqbal 08]や，アプリケーションの切り替えタイミングを用い る手法 [田中 10] も研究されている . しかし , これらの 
方法は web 閲覧等のアプリケーションを切り替えない作 業には適用できない．

他に, 各種センサを利用したユーザの作業の種類に基 づく忙しさの推定に関する研究や Web カメラを用いて ユーザの表情や姿勢を撮影し推定に用いる研究があるが [Fogarty 05, Chen 07, Jaimes 06] , 顔の撮影やセンサを ユーザに取り付けることは，観測されていることに対す るユーザの心理的負荷や，センサ自体の煩わしさなどが 問題になる.

弚こで本研究では, 机上にかかる圧力を利用した新し いユーザ状態推定手法を提案する.PC を用いる作業にお いて，机上にはキー入力の押圧や腕を乗せた際の力， 、 グカップの重さなど樣々な圧力か加わっている.また , 見 せられた文章の内容が肯定的か否定的かによって，無意 識のうちに握力の強弱に影響を与えるという研究結果が ある [Aravena 12]. これらのことは人間の心理状態力筋力 の強弱として表出する可能性を示唆している. 光のため, 弚れらの大きさと変化, すなわちキー押圧の強弱, 腕に 体重を乗せる度合いや位置，もしくはマグカップの中身 の減り方などには，ユーザ状態を推定するために有用な 情報が含まれていると考えられる . 例えば，人は熱中す れば自然と力が入り，キー押圧も普段より強い力で行っ たり，飲み物を口にする頻度か下がったりすることが考 えられる，作業に集中している間は前傾姿勢になるとい う報告 [木村 11] から，集中時は非集中時に比へ，腕に 体重を多くかけていることも考えられる .

また，机上にかかる圧力の測定はユーザにセンサを取 り付ける必要がなく，顔撮影のように個人情報を扱うも のでもないため, ユーザに物理的 , 心理的負荷を与える ことなく測定することができる .

本研究は, 机上にかかる圧力によって, 割り込み可能 か否かというユーザ状態の推定を実現することを目的と する. 従来研究には, 机上にかかる圧力によってユーザの 割り込み可能性を推定する研究は見当たらないため, 新 たなユーザ状態の推定方法を開発するという意味におい て, 本研究は方法論的な新規性をもつと考える. 乥して, 本研究は, ユーザに物理的心理的な負担を与えない, 新 しいユーザ状態推定法を提案することにより，ユーザ状 態に基づく情報通知の実現に貢献できる価值をもつ。

\section{2. 圧カセンサによるユーザ状態推定}

\section{$2 \cdot 1$ 圧カセンサ}

机上にかかる圧力を測定するため，机上に格子状に測 定点を持つ圧カセンサシートを敷く．これにより机の上 の平面上の圧力分布を測定する.キーボード等机上に置 く物はすべてこのセンサシート上に置き，作業もシート 上で行う.実際に 2 種類のキーボード (KFK-EA4XA (株) ミツミ電機，Realforce 91 NE0100 (株) 東プレ) を用いて， 光の位置を日常的に妥当な範囲でずらしながら使用時の

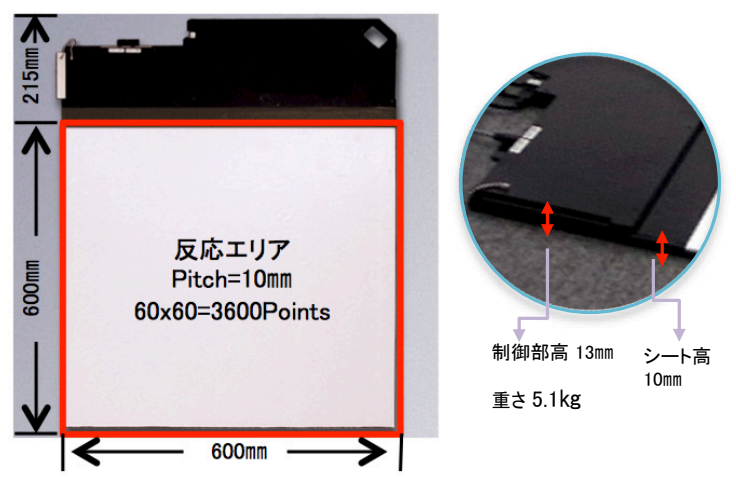

図 $1 \mathrm{LL} \mathrm{Sensor} \mathrm{*1}$

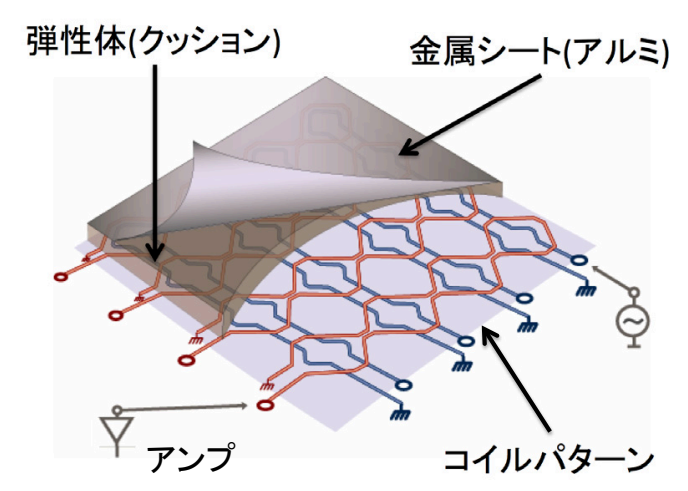

図 2 LL Sensor の原理図*1

圧力を測ってみるという予備調査を行った . 乥の結果, 主 にキーボードのタイピング圧力を計測するためには, セ ンサシートの大きさは $1 \mathrm{~m}$ 四方程度, 圧力分解能は $10 \mathrm{~g}$ 程度が必要であることがわかった 。

これらの分解能を満たす圧力センサシートとして, 本 研究では図 1 に示す LL Sensor((株) シロク, 大きさ： $600 \mathrm{~mm} \times 600 \mathrm{~mm})$ を利用した . 一般的に知られる圧力セ ンサには感圧抵抗方式や静電容量方式などがあるが, LL Sensor は電磁誘導を利用した圧力センサシートで, 静電 式や抵抗式と比較して大面積のセンサを低価格に実現で きる特徵がある．また，シート自体はごく薄いもの(厚 さ $10 \mathrm{~mm})$ であり，光の上での作業に違和感はない，図 2 にLL Sensor の原理図を示す . 上方から圧力が加わるこ とで弾性体の厚みが変化し, 金属シートとコイルパター ンとの距離が短くなる.これにより行方向コイルと列方 向コイルとの間の相互誘導が変化し, 圧力変化を電気信 号として取り出すことができる．

また，圧力分解能は使用する弾性材により調整可能で あり，既にキー押圧の強弱検知が可能なように調整済み である .センサ出力の例を图 3 に示す .ただし , センサの 出力は物理量ではなくセンサ独自の尺度である.この图 では, 出力值の低い方から順に白 (指示值 0 5), 青 (5〜

*1 http://www.llsensor.com/ 


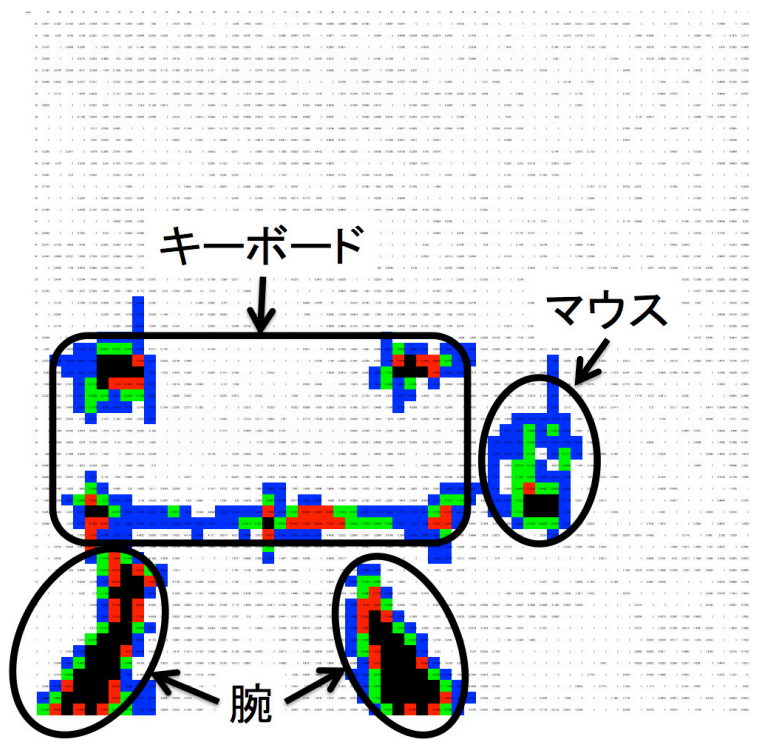

図 3 LL Sensor の出力

10) , 緑 $(10 \sim 15)$, 赤 (15〜20), 黑 (20〜) に着色してあ る .この例ではセンサシート上にキーボードとマウスを 配置しタイピングを行なっている．楕円で示した部分に 腕が, 四角で示した部分にキーボードが, 光の右側にマ ウスが置かれていることが見て取れる .

\section{$2 \cdot 2$ 特徵量抽出}

次に, 圧力データから特徵量を抽出する . 特徵量は, 前 述のようなキー押圧や乗せている物体の重さ，位置，光 れらの変化などである .

本研究では, 机上に圧力を与える物体はキーボードと マウス, ユーザの腕のみであるとし，モニタは圧力セン サのゼロ点補正により影響を排除した．ただし，将来的 には本やマグカップなど，多くの物体が置かれた環境に 適用できると考えられる．

後述する実験ではタイピングとマウス操作の光れ光れ について典型的なタスクを使用するが，PC を用いたー 般的なオフィスワークでは，マウスの利用が必須であり， マウスの圧力の特徵はユーザ状態推定にとって重要と考 えられる . さらに, 腕から得られる情報は重要であると 考えられる．

以上のような考察から，本研究では表 1 のように，以 下の 24 個の值を特徵量として使用する . キーボードの 左奥足・右奥足・手前足，マウス，ユーザの左腕・右腕 の計 6 個の圧力关れ光れに対し，圧力值 (Pressure)，面 積 (Area), 重心の $\mathrm{x}$ 座標 $\left(\mathrm{CoG}_{x}\right)$, 重心の $\mathrm{y}$ 座標 $\left(\mathrm{CoG}_{y}\right)$ の 4 個のパラメータを抽出した .

元の圧力データから特徵を抽出するために，単純なパ ターンマッチングアルゴリズムを使用した . 事前にキー ボードとマウス光れ光れの圧カマップを取得，正規化し， マッチングのパターンとした . 光して , パターンを用い
表 1 使用する特徵量

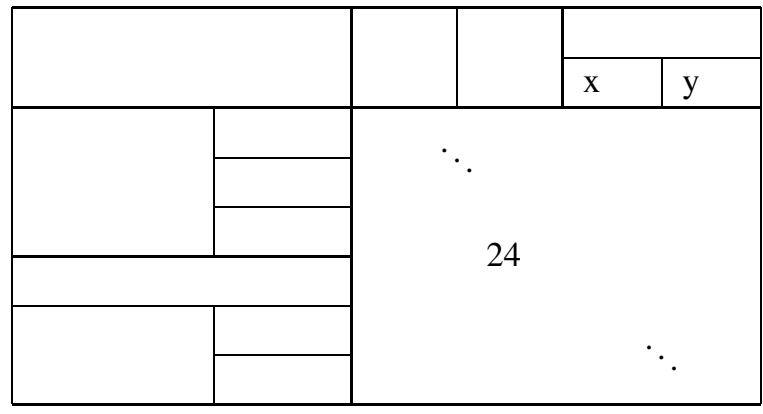

て圧力データを走査することで , パターンに対応する領 域を抽出した . また，左右の腕の位置を得るために，デー 夕全体を右下及び左下から走査し，しきい值を使用して 領域を抽出した . なお，領域抽出の精度を一部のデータ を用いて調査したところ，約 $90 \%$ 程度であった．关の 後, 各領域に対し, 圧力, 面積, 重心を算出する。

圧力データは $30 \mathrm{~ms}$ 毎に 1 フレーム得られる.また，特 徵は割り込みの 1 秒前から 9 フレーム分のデータを平均 して使用する .

\section{$2 \cdot 3$ 推 定 方 法}

特徵抽出後, 得られた特徵をべクトルとして, 分類学 習アルゴリズムに入力して , 分類学習を実行し , 割り込 み可能か否かを分類できるクラシファイアを学習により 得る . 実稼働時には , ユーザによる机上の圧力をモニター しながら，事前に得られたクラシファイアを適用するこ とで, 割り込み可能か否かの判定が可能となる .

実験では , 高精度のアルゴリズムとして SVM(Support Vector Machines)[Vapnik 95] と Random Forests[Breiman 01]の2つと，従来からよく用いられる C4.5[Quinlan 93] を使用し，光れらのパフォーマンスを比較検討すること にした.SVM は 2 クラス分類器の 1 種で, 訓練データ 群から各データ点との距離が最大となる超平面を求め, 关れを判別関数として用いる手法である . 汎化能力が高 く，カーネルトリックを用いることで非線形分類問題に も応用できる . Random Forests はアンサンブル学習の 1 種で , 決定木を弱学習器とするものである . 決定木の学 習が独立しているため並列に処理が可能であり，学習や 評価が高速である . C4.5 は ID3[Quinlan 86] の拡張であ り，決定木を生成するアルゴリズムである . 決定木の各 ノードには, 情報量が最大になるような分類が選択され る. SVM と Random Forests は C4.5 より高い精度が得 られることが予想されるが，C4.5 は学習結果が決定木 1 つで与えられるため, 可読性が高い .

\section{3. 評 価 実 験}

\section{$3 \cdot 1$ 実験環境とタスク}

本研究ではユーザが PC を利用したデスクワークを している環境を想定しているが，本実験ではできるだ 
け一般的で単純化したデスクワーク環境とタスクを構 築した . 図 4 に実験の樣子を示す . キーボードはSKBLKG3BK((株) サンワサプライ)，マウスは LS-1BK((株) Logicool) , ディスプレイは DELL 2001FP(20.1 インチ解 像度 $1600 \times 1200), \mathrm{PC}$ は Let's s note CF-R9((株)Panasonic CPU : Core i7 620UM/1.06GHz メモリ : 2GB OS : Windows 7 Professional SP1 32bit) を使用した .このPC は， ディスプレイ描画及び圧力データの記録に使用した .タス クは，PCによるデスクワークとして考えられる典型的な タスクとして, 情報通知の先行研究 [Iqbal 08]で用いられ ているタスクを参考にして，タイピングタスクとマウス操

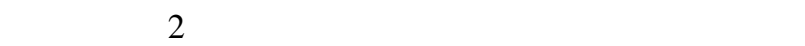
段を右から左にスクロールする文字列をできるだけ正確 に書き写すタスクである (図 6(a)) . 表示される文字はラ ンダムなローマ字文字列で, タイピングされた文字列は画 面下段に表示される．画面サイズは 500pixel×300pixel， 表示文字は MSP ゴシック，30pixel である . 押下された キーはキーコードと時刻をすべて記録される．スクロー ル速度を変化させることにより, タスクの負荷を調整す る、タイピング中，割り込みを許容するか否かを尋ねる ダイアログ (図 7) が 20 秒間隔で画面中央に表示される . 割り込みに対する回答には，回答の動作が机上の圧力に 与える影響を最小限に留めるために, 图 5 のようなフッ トスイッチを用いた . 参加者は用意された 2 つのフット スイッチのうち, 許可 (accept) なら左のフットスイッチ を，拒否 (reject)なら右のフットスイッチを踏むことで回 答する . 参加者には , 食事の誘いのような , 緊急性が低 い情報か提示されることを想定して可否を決定するよう 教示を与えた . 回答するとダイアログは消え , メインタ スクを再開する．

マウス操作タスクは , 図 6(b) の画面を使用し，青く四 角いマーカをクリックするタスクである . マーカは一定 周期 (数秒間隔) でランダムな位置に表示され，次の四角 が表示されると同時に消える．消えるまでにクリックに 成功すると，色が赤に変化してから消える．表示周期を 変化させることにより, タスクの負荷を調整する.クリッ クした位置と時刻は四角の内外に関わらずすべて記録さ れる．画面サイズは 500pixel ×500pixel，マーカサイズ は 20pixel×20pixelである .タイピングタスクと同樣に ダイアログが表示される .

\section{$3 \cdot 2$ 参加者と実験手順}

参加者は情報系専攻の大学院生と研究所職員の 20 名 (23 歳 5 4 歳, 平均 33.7 歳, 標準偏差 9.9 歳, 男性 9 名, 女性 11 名)であった。

許可と拒否の両方のデータを得るために ,メインタス クの負荷が高いフェーズと低いフェーズが必要である.負 荷が高いフェーズでは, メインタスクに集中する必要が あるため，参加者は通知を拒否し，負荷が低いフェーズで は,メインタスクに集中する必要がないため,参加者は通

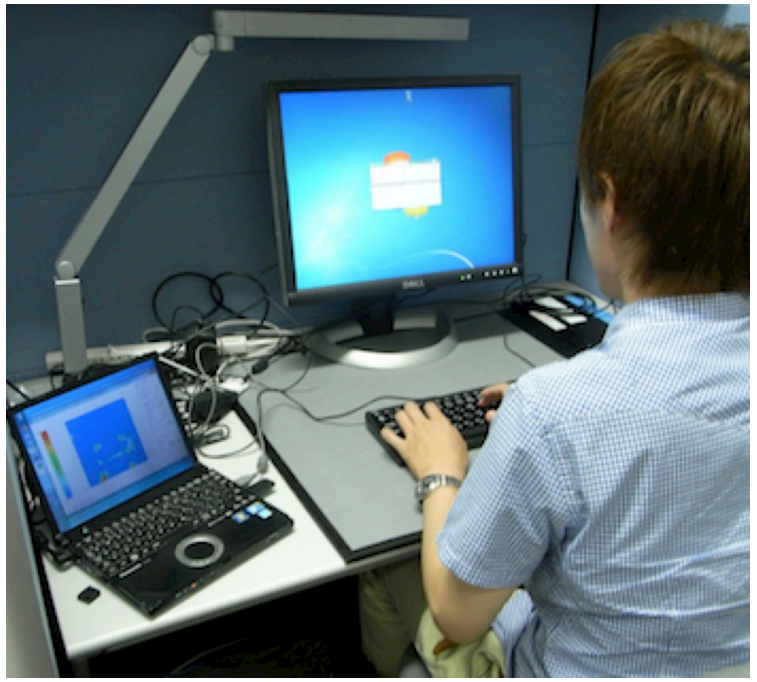

図 4 実験環境

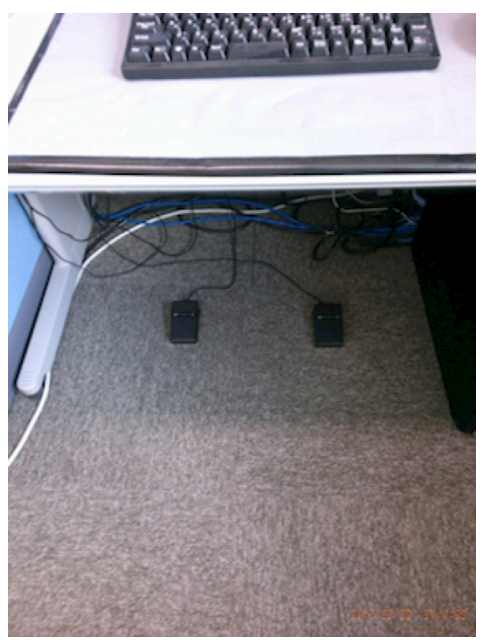

図 5 実験環境のフットスイッチ

知を許可することが予想されるからである．乥こでタイ ピングタスクではスクロール速度を $1 / 12 \mathrm{pixel} / \mathrm{ms}, 1 / 20$ $\mathrm{pixel} / \mathrm{ms}, 1 / 30 \mathrm{pixel} / \mathrm{ms}, 1 / 40 \mathrm{pixel} / \mathrm{ms}, 1 / 50 \mathrm{pixel} / \mathrm{ms}$, $1 / 60 \mathrm{pixel} / \mathrm{ms}$ の 6 段階 , マウス操作タスクでは表示間隔 を $1.2 \mathrm{~s}, 1.5 \mathrm{~s}, 2 \mathrm{~s}, 3 \mathrm{~s}$ の 4 段階の負荷を用意した .これら の負荷は，予備実験により，最も熟練した参加者がかろ

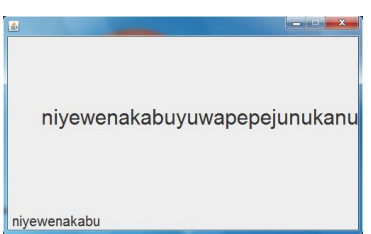

(a) タイピング

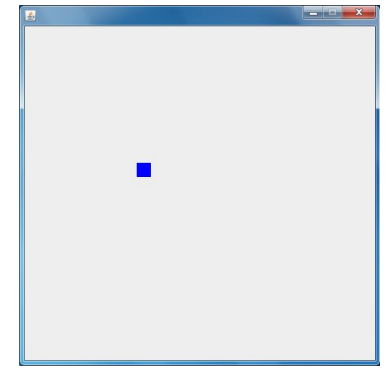

(b) マウス操作
図 62 つのタスクにおけるタスクウインドウ 


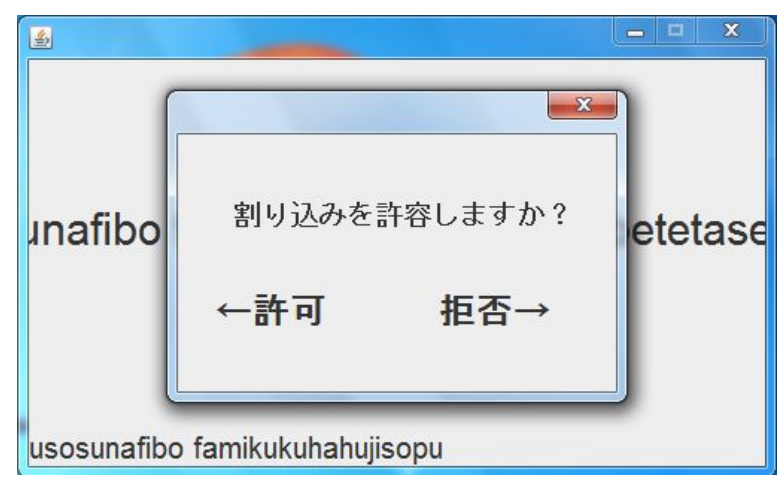

図 7 情報通知ダイアログ

うじて追従できる速度を上限とし，乥の近傍では微調整 が可能なように間隔を決定した，光して，各参加者に対 し，実験に入る前にタイピング能力やマウス操作能力を 調査し, 負荷にかろうじて追いつけるものを中負荷, 光 れより一段階低いものを低負荷，一段階高いものを高負 荷として，3 段階の負荷を与えた。

負荷調整の後，本実験を行った . 各参加者に対し，2つ のタスクを弚れ光れ 2 回試行，すなわち計 4 試行とした . 各試行では, 1 分を 1 フェーズとして負荷が高いフェーズ と低いフェーズを織り交ぜ, 5 フェーズ行った . 各フェー ズ中, 20 秒間隔で 3 回通知を行った . 総計で 20 分間夕 スクを行うことになる．

分類学習の実装として，一般的なデータマイニングプ ログラムライブラリである weka3.5.4 $4^{* 1}$ 上に実装された， Random Forests(number of trees = 10 )，SVM の実装で ある LibSVM(RBF kernel , $\gamma=0.042) ， \mathrm{C} 4.5$ の実装であ る J48(confidence factor $=0.25$ ) を使用した 。

\section{$3 \cdot 3$ 実 験 結 果}

表 2 に得られた特徵量を抜粋して挙げる.この表から は, accept と rejectの間で, 各特徵量の值に大きな差は見 られない，得られたデータ数は全体で 1199 個 (許可 722 ， 拒否 477)，内タイピングタスクは 600 個 (許可 333 , 拒否 267)，ママウス操作タスクは599個 (許可 389 ,拒否 210) で ある.なお今回の実験では, 全参加者のデータをまとめた ものを使用して分類を行う. 許可と拒否のデータ数に大き な差が見られなかったため, 正データ・負データの量のイ ンバランスを補正するアンダーサンプリング [Drummond 03] は適用しなかった .

次に, 得られたデータを 3 つの分類学習に与え, 交差 検定 (10-fold) による学習実験を行った．実験結果として， 各学習アルゴリズムにより学習されたクラシファイアの 精度を表 3 に示す.ここで精度は, 許可/拒否の 2 クラ スについて正しく分類された訓練データの割合である .

表 3 から, タイピングタスク, マウス操作タスク, 両夕 スク総計のいずれの条件でも，SVM が最も高い精度を達

\footnotetext{
*1 http://www.cs.waikato.ac.nz/ml/weka/
}

表 2 データの例 (左腕)

\begin{tabular}{|c|c|c|c|c||c|}
\hline & Area & Pressure & $\mathrm{CoG}_{x}$ & $\mathrm{CoG}_{y}$ & クラス \\
\hline 左腕 & 29.6 & 36.4 & 54.9 & 341.4 & \\
右腕 & 15.6 & 22.4 & 7.3 & 43.3 & \\
左足 & 77.4 & 83.6 & 1616.9 & 3027.5 & reject \\
右足 & 70.2 & 122.0 & 1089.3 & 1362.1 & \\
手前足 & 28.6 & 58.5 & 346.1 & 113.7 & \\
マウス & 3.9 & 9.1 & 12.8 & 61.3 & \\
\hline 左腕 & 29.4 & 36.7 & 54.2 & 341.9 & \\
右腕 & 18.4 & 23.6 & 10.0 & 44.5 & \\
左足 & 75.5 & 85.3 & 1615.7 & 3027.0 & reject \\
右足 & 69.1 & 125.0 & 1088.3 & 1363.9 & \\
手前足 & 31.7 & 56.8 & 343.0 & 1363.9 & \\
マウス & 4.9 & 9.8 & 12.3 & 61.4 & \\
\hline 左腕 & 28.4 & 37.5 & 55.5 & 341.2 & \\
右腕 & 17.8 & 24.2 & 9.8 & 44.2 & \\
左足 & 76.0 & 83.6 & 1615.2 & 3027.1 & \multirow{2}{\text{a}}{ accept } \\
右足 & 69.9 & 121.9 & 1088.6 & 1364.1 & \\
手前足 & 30.4 & 56.4 & 344.3 & 61.4 & \\
マウス & 5.4 & 10.4 & 11.8 & 61.4 & \\
\hline 左腕 & 27.9 & 38.0 & 54.7 & 341.2 & \\
右腕 & 17.7 & 23.7 & 9.5 & 44.4 & \\
左足 & 77.7 & 86.4 & 1616.0 & 3027.0 & accept \\
右足 & 70.5 & 124.1 & 1089.5 & 1364.8 & \\
手前足 & 30.8 & 58.0 & 345.6 & 113.8 & \\
マウス & 5.0 & 10.1 & 11.8 & 61.4 & \\
\hline
\end{tabular}

表 33 つの分類学習アルゴリズムの精度 (下線が各タスクの最良 值 , 太字がすべてにおける最良值)

\begin{tabular}{|c||c|c|c|}
\hline \multicolumn{1}{|c||}{} & \multicolumn{3}{c|}{ 精度 [\%] } \\
\hline 分類学習 & タイピング & マウス操作 & 全体 \\
\hline SVM & $\underline{\mathbf{7 6 . 8}}$ & $\underline{\mathbf{7 2 . 3}}$ & $\underline{\mathbf{7 3 . 6}}$ \\
Random Forests & 75.8 & 69.6 & 73.1 \\
C4.5 & 71.7 & 71.6 & 71.3 \\
\hline
\end{tabular}

成しており，本研究ではSVM を適用すべきである．ま た , タイピングタスクの方がマウス操作タスクよりも，高 い精度で割り込み可能性を判定できていることがわかる．

\section{4. 考察}

\section{$4 \cdot 1$ 机上の圧力を用いた状態推定の評価}

実験の結果 , タイピングタスクでは約 77\% ，マウスタ スクでは約 $72 \%$ の精度でユーザの割り込み可能性を推定 することができた (表 3) . 職場での PC を用いたデスク ワークの大半は文書作成であると考えられるため, タイピ ングタスクの結果である約 77\% が重要である .チャンス レベルは約 50\%であるため，机上の圧力から得た情報に， 割り込み可能性推定に有用な情報が含まれていることが 示唆された .これは , 机上の圧力を用いたユーザの状態 
推定を目指した先駆的な研究として，今後の発展を見込 める結果だと考えられる . また，提案手法はコンピュータ ビジョン [Fogarty 05]やタイピングパターン [Epp 11] 利用した既存の手法とモダリティが干渉しないため，光 れらと組み合わせた利用も可能である .

一方，表 3 のSVM の精度を見ると，ママウス操作タス クの推定精度はキーボードタスクより低い．この原因と して , キーボードの足の押圧に比べ , マウスの押圧は LL Sensor で測定が困難である可能性や，ママウス操作による 押圧の変化が少ないことなどが考えられる．マウスス操作 タスクについて推定精度を向上することは, タスク全体 の推定精度の向上と共に, 今後の重要な課題である。

\section{$4 \cdot 2$ キーボード, マウスの非操作時における状態推定}

提案手法では, ユーザがタイピングやマウス操作を行 なっていない間は机上の圧力に変化がないため, 割り込 み可能性は推定できない，乥こで本研究では, ユーザが キーボードやマウスで作業をしていない間は割り込み可 能であると仮定している .

しかし実環境では必ずしも光のような仮定は成立しな い.例えば, 考え事, ウェブページ閲覧, 動画鑑賞などに 集中している時は , キーボードやマウスを操作していな い間でも割り込み不可能な状態が存在する .この問題に 対する対して提案手法による解決策として，特徵を拡張 することが考えられる.例えばマグカップの重量や, 腕 を机上に置いた際の形状などの特徵を追加することが簡 単にできる .これらは圧力センサで取得可能な情報であ る、ユーザが集中状態にあれば，マグカップを頻繁に取 り上げなくなる, 腕の位置を変えなくなるなどの現象が 予想されるため，これらの特徵により机上の圧力による 解決が期待できる。

\section{$4 \cdot 3$ 時系列特徵の効果}

前節の評価実験においては，ある時刻における 24 特 徵のスナップショットをデータとして利用したが , 異な る時刻のデータ間の差分が有益な情報を持っている可能 性がある. 光こで, 光のような圧力の時間変化にユーザ 状態推定に有用な情報が含まれているか検証するために， 图 8 のように, 時系列上のデータを複数, 及び差分を与 えて推定を行った . 弚の結果の一部を表 4 に示す．ここ で, 各数字は情報通知と使用したデータとの時間差を表 し", -”は光の差分をデータとして使用していることを表 す．すなわち “" $1 \mathrm{~s} ”$ は割り込み発生の 1 秒前のデータを 用いており，これは表 3 のタイピングタスクの結果と同

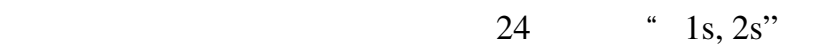
割り込み発生の 1 秒前と 2 秒前のデータを用いており， 各データ採取ポイントから 24 特徵量が得られるため，あ わせて 48 特徵量を用いて学習及び分類を行なっている. “ $1 \mathrm{~s}-2 \mathrm{~s} ”\left(\mathrm{z}_{1} り\right.$ 込み発生の 1 秒前と 2 秒前のデータの差 分を用いており, 各特徵量毎に差を取るため, 特徵量の

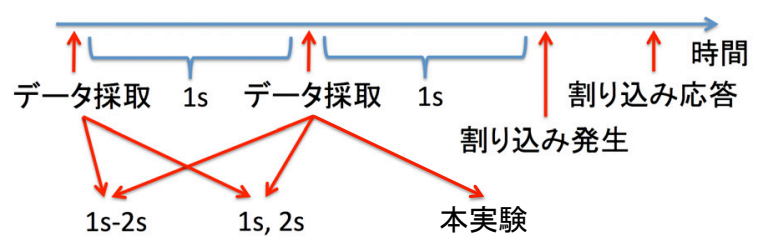

図 8 圧力測定のタイムライン

表 4 時系列データを使用した場合の推定精度 (下線が各学習アル ゴリズムの最良值，太字はすべてにおける最良值)

\begin{tabular}{|c||c|c|c|c|}
\hline \multicolumn{1}{|c||}{} & \multicolumn{4}{c|}{ 精度 [\%] } \\
\hline 学習アルゴリズム & $1 \mathrm{~s}$ & $1 \mathrm{~s}, 2 \mathrm{~s}$ & $1 \mathrm{~s}, 1 \mathrm{~s}-2 \mathrm{~s}$ & $1 \mathrm{~s}-2 \mathrm{~s}$ \\
\hline SVM & $\underline{\mathbf{7 6 . 8}}$ & 74.3 & 74.0 & 57.0 \\
Random Forests & $\underline{\underline{73.2}}$ & $\underline{73.2}$ & 66.7 & 61.2 \\
C4.5 & $\underline{68.5}$ & 68.7 & 61.2 & 55.5 \\
\hline
\end{tabular}

数は 24 となる .

図 8 に示した他にも [1s,5s] [1s,10s] [1s-3s] [1s-2s, 1s3s]など 11 通りの組み合わせを調査したが, いずれも当 初の精度を上回ることはなく, 本研究で採用した 24 特 徵量について, 圧力の時間変化にはユーザ状態推定に有 用な情報は乏しいか存在しないことか実験的に示された . しかし, 当然ながら本実験で採用しなかった特徵量につ いてはこの限りではない.例えばマグカップの重量は, 内 容物の減り方が状態推定に寄与していることが直観的に 予測できる。

一方，時系列データを使用せず，情報通知からの時間 差を $30 \mathrm{~ms}$ から $10 \mathrm{~s}$ の間で变化させた結果, 各学習アル ゴリズムでの最高精度は，Random Forests は 200msで， $\mathrm{C} 4.5$ は $5 \mathrm{~s}$ で, いずれも $74.8 \%$ となった .これらは SVM には及ばないが, 学習アルゴリズム毎に調整を行うこと で精度が向上する可能性を示唆している。

\section{$4 \cdot 4$ より実用的な特徵選択}

これまでの実験により提案手法の有効性を確認できた が, LL Sensor は微小な圧力センサを格子状に持つ特殊な センサで, 容易に入手できる安価なセンサではない. 従っ て実用にはコストが問題となる .この問題の解決法とし て, 図 9 に示す, FSR406 (Interlink Electronics Inc.) の ような, 小さく安価な圧力センサを使用することが考え られる.このような小さなセンサはキーボードの 3 つの 足とマウスの底面に簡単に取り付けることができる .こ の手法でLL Sensor を使用した場合と同等の精度で状態 推定が可能ならば，提案手法はより実用的なものとなる． このような小型のセンサを計測点に貼り付ける手法は， 実験で獲得した 24 の特徵量データのうち, キーボード やマウスが机上に与える圧力の特徵量だけを用いて推定 することにより，シミュレートできる．SVMによって上 記の特徵量から推定した結果を表 5 に示す .なお，この 表で, 一番下の行の「すべての特徵量」が, LL sensor を 


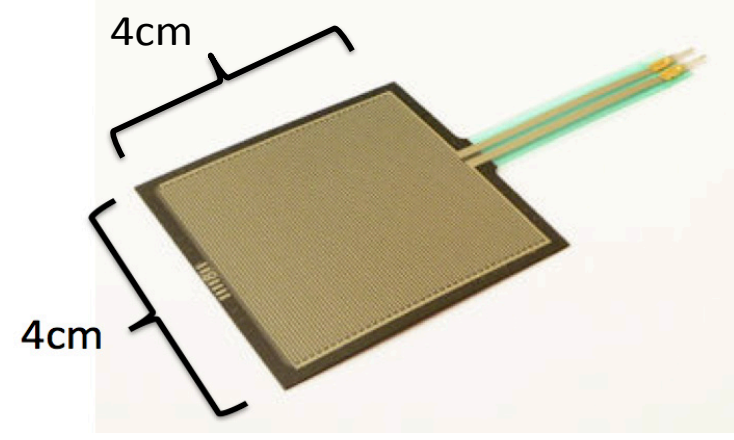

図 9 小型で安価なセンサ

表 5 局所的にセンサを配置した場合の推定精度

\begin{tabular}{|c||c|c|c|}
\hline \multicolumn{1}{|c||}{} & \multicolumn{3}{c|}{ TP Rate [\%] } \\
\hline 選択された特徵 & タイピング & マウス操作 & 全体 \\
\hline キーボードの圧力 & 74.7 & - & - \\
マウスの圧力 & - & 64.3 & - \\
キーボード圧+マウス圧 & 75.8 & 70.0 & 69.8 \\
すベての特徵量 & 76.8 & 72.3 & 73.6 \\
\hline
\end{tabular}

用いた場合の表 3 のSVM の結果である . タイピングタ スク, マウス操作タスクの炎れ光れについて , キーボー ドとマウスの特徵量だけを用いた場合と，すべての特徵 量を用いた場合で，ほぼ同等の精度が得られたことがわ かる．よって，キーボードの足とマウスの裏に図 9 のよ うな小型の圧力センサと装着できる環境においては , 提 案方法をより実用的に利用できることがわかった .

また，他の特徵選択の方法として，圧力センサを平面 全体に敷かず，机の手前から $5 \mathrm{~cm}$ や $10 \mathrm{~cm}$ などの位置に 横一列の直線上に配置する手法が考えられる . 兴のよう な手法の有効性は, 図 10 のように，実験で得られた平面 のデータから，直線上にあるセンサを手前から奥に走査 することでシミュレートできる．ここで，抽出する特徵 量は次の 4 つとした .

・圧力が掛かっている範囲 (長さ)

・圧力が掛かっている個数 (腕が 2 本あれば 2 個 , など)

- 重心

- 圧力の平均値

この手法を用いてタイピングタスクについて SVM を 用いて状態推定した場合の推定精度を図 11 に示す.ここ で, 青線は 24 特徵量すべてを使用した場合で, 表 3 の夕 イピングタスクをSVM を用いて推定した場合と同一で ある.すべての特徵量を用いた場合と比較して若干劣る が , 机の手前からの距離が $3 \mathrm{~cm} \sim 4 \mathrm{~cm}$ 及び $20 \mathrm{~cm} \sim 26 \mathrm{~cm}$ の範囲において，LL sensor を使った場合とほぼ同等の 精度が得られたことがわかる．つまり，この実験結果に より，ある範囲に横一列に小型圧力センサーを設置する ことで, LL sensor と同程度の割り込み可能性の推定が 可能であることが示唆されたと言える .

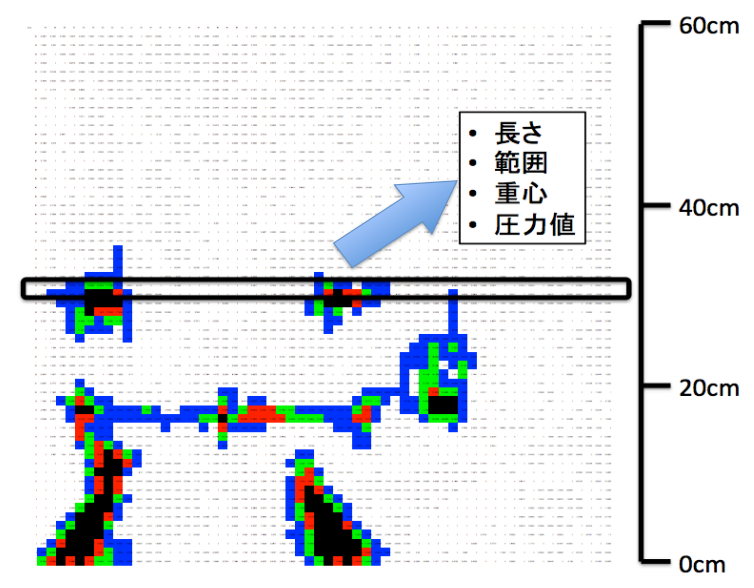

図 10 直線状にセンサを配置した場合のシミュレート

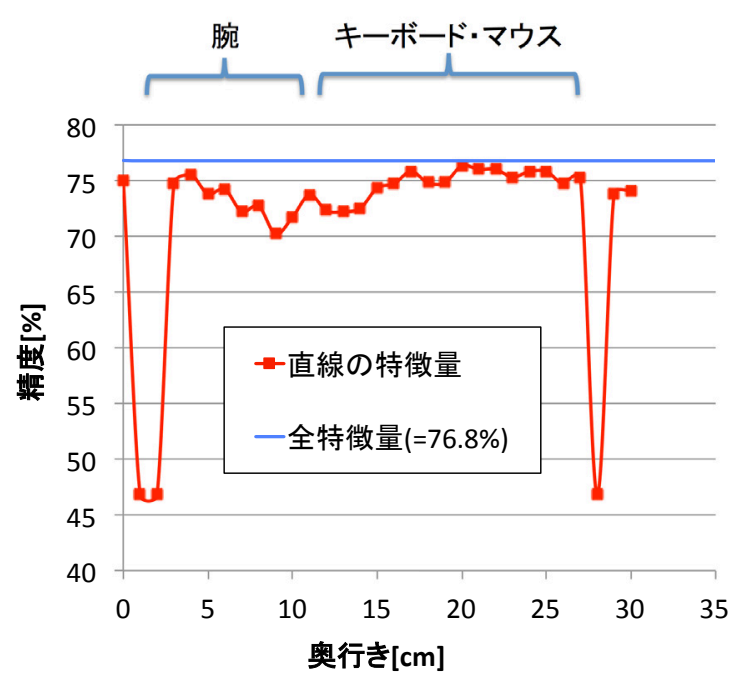

図 11 直線状にセンサを配置した場合の推定精度

また，腕が置かれている領域 (奥行き $0 \mathrm{~cm} 〜 10 \mathrm{~cm}$ ) と キーボードやマウスが置かれている領域 $(10 \mathrm{~cm} 〜 30 \mathrm{~cm})$ の両方から同程度の精度で推定できていることから，こ れらの圧力にも，推定に有用な情報が含まれていること がわかった . 一方, 机の手前からの距離が $1 \mathrm{~cm} \sim 2 \mathrm{~cm}$ 及 び $28 \mathrm{~cm}$ の位置で極端に精度が落ちているが，これはセ ンサの劣化により一部のセンサセルの精度が悪化し，圧 力を正確に測定できていなかった可能性があり, 該当セ ンサを使用する推定が正常に行われなかったことが原因 と考えられる .

以上のことから，前述の安価なセンサの利用と共に，設 置条件か許されれば, 直線上のセンサ配置も実用的な特 徵として有効であることがわかった .

\section{5.む す び}

本研究では, PC を用いたデスクワークを行うユーザ状 態の新たな推定手法として , 机上の圧力を用いることを 
提案した . 圧力センサを用いて特徵量のデータを計測し， そのデータを入力として分類学習アルゴリズムによる学 習を行い, 学習されたクラシファイアにより割り込み可 能性を自動判定することが可能になる.光して，2つの 典型的なデスクワークタスク中に情報通知を与える参加 者実験を行い, 提案手法によりユーザの割り込み可能性 を推定することにより，提案手法の有効性を実験的に検 証した . また, 提案手法の精度と実用可能性に関して考 察した。

実験の結果，キーボードを用いた書き写しタスクを行 なっているユーザについて, 割り込み可能性を $77 \%$ の精 度で推定に成功した .この結果は，ユーザが机上に加え る圧力に，ユーザ状態推定に有効な情報が含まれている ことを示している．また提案手法の有効性を示唆してお り，今後の展望に期待できると言える .

一方, 圧力の時間变化を用いた状態推定について検証 した結果, 瞬間值を用いた場合と比へて精度の向上は見 られなかった . これは圧力変化量が状態推定に有用な情 報を含んでいないか，非常に乏しいことを示している．

また，小規模で安価なセンサを用いて推定することを 検証した結果，キーボードや腕など局所的にセンサを配 置することで, 机上全体をセンサで覆った場合と同等の推 定精度が得られ，容易に実用可能であることが示された．

今後の課題として，実環境に適用するため，より豊富 な特徵量を利用することが挙げられる．これにより，精 度の向上と非タイピング時における推定を可能にできる。 兴のために，有効な特徵を模索する。また，より多くの データを収集し，実験の正確性を高める。

\section{$\diamond$ 参 考 文 献 $\diamond$}

[Aravena 12] Aravena, P., Delevoye-Turrell, Y., Deprez, V., Cheylus, A., Paulignan, Y., Frak, V., and Nazir, T.: Grip Force Reveals the Context Sensitivity of Language-Induced Motor Activity during "Action Words" Processing: Evidence from Sentential Negation, PLoS ONE, Vol. 7, No. 12, p. e50287 (2012)

[Bailey 01] Bailey, B. P., Konstan, J. A., and Carlis, J. V.: The Effects of Interruptions on Task Performance, Annoyance, and Anxiety in the User Interface, in Proceedings of INTERACT'01, pp. 593-601 (2001)

[Breiman 01] Breiman, L.: Random Forests, Machine Learning, Vol. 45, No. 1, pp. 5-32 (2001)

[Chen 07] Chen, D., Hart, J., and Vertegaal, R.: Towards a physiological model of user interruptability, in Proceedings of the 11th IFIP TC 13 international conference on Human-computer interaction - Volume Part II, INTERACT'07, pp. 439-451 (2007)

[Drummond 03] Drummond, C. and Holte, R.: C4.5 and class imbalance and and cost sensitivity: why under-sampling beats oversampling, in Workshop on Learning from Imbalanced Datasets, pp. $1-8$ (2003)

[Epp 11] Epp, C., Lippold, M., and Mandryk, R.: Identifying Emotional States Using Keystroke Dynamics, in Proceedings of the 2011 Annual Conference on Human Factors in Computing Systems (CHI 2011), pp. 715-724 (2011)

[Fogarty 05] Fogarty, J., Hudson, S. E., Atkeson, C. G., Avrahami, D., Forlizzi, J., Kiesler, S., Lee, J. C., and Yang, J.: Predicting human interruptibility with sensors, ACM Transactions on Computer-Human Interaction, Vol. 12, No. 1, pp. 119-146 (2005)
[Iqbal 08] Iqbal, S. T. and Bailey, B. P.: Effects of intelligent notification management on users and their tasks, in Proceedings of the twenty-sixth annual SIGCHI conference on Human factors in computing systems, pp. 93-102 (2008)

[Iqbal 10] Iqbal, S. T. and Bailey, B. P.: Oasis: A framework for linking notification delivery to the perceptual structure of goal-directed tasks, ACM Transactions on Computer-Human Interaction, Vol. 17, pp. 1-28 (2010)

[Jaimes 06] Jaimes, A.: Posture and activity silhouettes for selfreporting, interruption management, and attentive interfaces, in Proceedings of the 11th international conference on Intelligent user interfaces, IUI '06, pp. 24-31 (2006)

[Kim 10] Kim, T., Hong, H., and Magerko, B.: Design requirements for ambient display that supports sustainable lifestyle, in Proceedings of the 8th ACM Conference on Designing Interactive Systems, DIS '10, pp. 103-112, New York, NY, USA (2010)

[McCrickard 01] McCrickard, D. S., Catrambone, R., and Stasko, J. T.: Evaluating Animation in the Periphery as a Mechanism for Maintaining Awareness, in Proceedings of the IFIP TC.13 Conference on Human-Computer Interaction (INTERACT'01), pp. 148-156 (2001)

[Quinlan 86] Quinlan, J. R.: Induction of Decision Trees, Mach. Learn, pp. 81-106 (1986)

[Quinlan 93] Quinlan, J. R.: C4.5: programs for machine learning, Morgan Kaufmann Publishers Inc. (1993)

[Vapnik 95] Vapnik, V. N.: The nature of statistical learning theory, Springer-Verlag New York, Inc. (1995)

[水口 04] 水口充, 竹内 友則, 倉本 到, 渋谷雄, 辻野嘉宏 : デスク ワークにおける忙しさの自動推定, ヒューマンインタフェース学 会論文誌, Vol. 6, No. 1, pp. 69-74 (2004)

[田中 10] 田中 貴紘, 松村 京平, 藤田 欣也 : 利用アプリケーショ ン切り替え時に着目したユーザの割り込み拒否度推定法の検討, 人工知能学会論文誌, Vol. 25, No. 6, pp. 683-693 (2010)

[本田 98] 本田 新九郎, 富岡 展也, 木村尚亮, 大澤 隆治, 岡田 謙一, 松下温: 作業者の集中度に応じた在宅勤務環境の提供 : 仮想才フィ スシステム, 情報処理学会論文誌, Vol. 39, No. 5, pp. 1472-1483 (1998)

[木村 11] 木村 和行, 田中 貴紘, 藤田 欣也 : 頭部の前後・回転運動 に着目したデスクワーク中の割り込み拒否度と頭部運動の関係 の分析, 情報処理学会論文誌, Vol. 52, No. 4, pp. 1485-1494 (2011)

〔担当委員 : 藤波 努〕

2013 年 7 月 12 日 受理

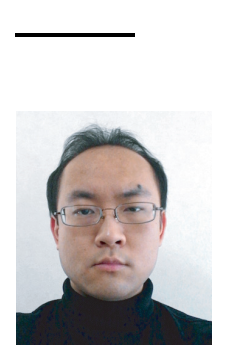

\section{者 紹}

\section{介}

\section{谷克尚}

2009 年東京工業高等専門学校専攻科電気電子工学専攻卒 業. 現在, 総合研究大学院大学複合科学研究科情報学専攻に 在学中. ユーザ状態推定に興味を持つ。

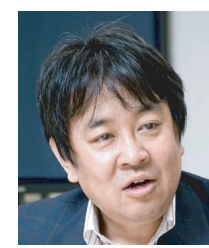

山田 誠二(正会員)

1984 年大阪大学基礎工学部卒業. 1989 年同大学院基礎工 学研究科博士課程修了. 工学博士. 1989 年大阪大学基礎 工学部助手. 1991 年大阪大学産業科学研究所講師. 1996 年東京工業大学大学院総合理工学研究科助教授. 2002 年国 立情報学研究所教授, 現在にいたる.HAI ヒューマンエー ジェントインタラクション, 知的インタラクティブシステム に興味をもつ. 情報処理学会, 日本ロボット学会, AAAI, IEEE, ACM 各会員. 